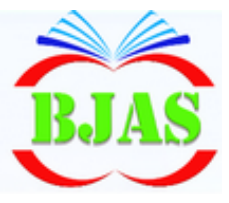

ISSN $1814-5868$
Available online at http://bajas.edu.iq

https://doi.org/10.37077/25200860.2020.33.2.03

College of Agriculture, University of Basrah
Basrah Journal

of Agricultural

Sciences

\title{
Effect of Microwave and UV-C Radiation on Some Germination Parameters of Barley Seed Using Mathematical Models of Gompertz and Logistic: Analysis Study
}

\author{
Samir K. Lazim* \& Marwan N. Ramadhan \\ Department of Agricultural Machines and Equipment, College of Agriculture, University of \\ Basrah, Iraq \\ *Corresponding author-mail: samir.lazim60@gmail.com
}

Received 21 June 2020; Accepted 20 August 2020; Available online 22 August 2020

\begin{abstract}
Two separated sets of laboratory experiments were studied for barley seeds treating using a microwave and ultraviolet irradiation. In the microwave set, seeds have been exposed to the microwave radiations $(2450 \mathrm{MHz})$ for $0 \mathrm{sec}$ (control, MW0), $5 \mathrm{sec}$ (MW1), $10 \mathrm{sec}$ (MW2), and $20 \mathrm{sec}$ (MW3), while in the ultraviolet set, seeds have exposed to UV-C radiation $(254 \mathrm{~nm}$ ) for $0 \mathrm{~min}$ (control, UV0), $30 \mathrm{~min}$ (UV1), $60 \mathrm{~min}$ (UV2), and $120 \mathrm{~min}$ (UV3). The aim is to study the influences of different exposure time from MW and UV-C radiation on some barley seed germination parameters and to choose the fitting model Logistic ( $\mathrm{Log}$ ) or Gompertz (Gom) suited to cumulative germination curves under the influence of these factors. The results of this study showed higher seed germination percentage $(93.33 \%)$ at the exposure time MW2 and UV3 (88.33\%), whereas the lowest value $(66.67 \%)$ recorded in MW3 treatment. The results also appeared the best values at MW2 in SG, 6.24 seed day ${ }^{-1}$; in GRI, $31.19 \%$ day $^{-1}$, and in GI, 87.67, as well as at UV2 in MGT, 3.32 day. The higher value of asymptotic germination barley seeds was found with Gom function $(97.24 \%$, and $88.71 \%$ ) at MW2 and UV3, respectively. Besides, Gom functions at MW1 and UV2 give the highest maximum germination rates at 2,08 and $2.51 \% \mathrm{~h}^{-1}$, respectively. The results of the Log equation illustrated the highest value of germination percentage of the inflection point has recorded in 43.85 and $47.37 \%$ on UV3 and MW2 treatments, respectively. For the fitting growth curve, the results have proven that the Gom function was shown the lowest values in MSE in all MW and UV exposure times, as compared with the Log function. So, the results of the Gom function were more fit for the growth curve for MW and UV treatments, as compared with the Log function.
\end{abstract}

Keywords: Microwave radiation, Ultraviolet radiation, Germination parameters, Logistic function, Gompertz function, inflection point.

\section{Introduction}

The physical treatment techniques can be considered one among the safest commons methods for increasing the seeds germination and plant growth, which is thanks to the less harmful influence on the environment. As well as, physical factors have used to get a positive biological change in the plants without affecting on the ecology (Govindaraj et al., 2017). Most perspective of the physical factors currently uses for seed treatments, for 
instance, electromagnetic waves, like ultraviolet and microwave radiation, ultrasound, laser, and ionizing radiation. Among the physical treatments, microwave and UV-radiation, especially, are considered the foremost important in pre-sowing seed treatments. (Araujo et al., 2016). Microwaves (MWs) are part of the electromagnetic spectrum, which is a non-ionizing electromagnetic with a high-frequency range from $300 \mathrm{MHz}$ to $\mathrm{GHz}$ with a wavelength range from $1 \mathrm{~m}$ down to $1 \mathrm{~mm}$ (Wang et al., 2018). Microwave radiation effects depend on radiation frequency and exposure period. Generally, low microwave exposure has been successfully used as a positive effect on the accelerating seed germination, while a long exposure usually tends to reduce plant growth. Recently, several authors reported the positive influence of MW on the barley seed germination at low MW exposure, while the longer exposure times have shown a negative effect on seed germination (Iuliana et al., 2013; Abu-Elsaoud \& Qari, 2017; Kretova et al., 2018). Besides, further studies conducted by Aladjadjiyan (2010), Amirnia (2014), AbuElsaoud (2015); Jakubowski (2015) and Mohsenkhah et al. (2018); whose indicated that MW can be used as a method of seed germination improvement in pepper, wheat, bean, soybean, and lentil respectively.

Ultraviolet (UV) radiation is considered electromagnetic radiation, and these radiations have traditionally divided into three wavelength ranges included UV-A (320390nm), UV-B (280-320nm), and UV-C (100280nm). Between these ranges, UV-C radiation is extremely active photochemical and biologically lethal and used by some authors as stimulated the germination of rate maize and Sugar Beet seeds (Sadeghianfar et al., 2019). Also, UV-C irradiation employed to increase seed germination and growth parameters of wheat (Nasur \& Lazim, 2001; Rupiasih \& Vidyasagar, 2016) groundnut (Neelamegam \& Sutha, 2015). Several researchers have used some statistical functions to analyzing the seed cumulative germination curves, like Gompertz function (Gupta et al., 2012; Sousa et al., 2014), Logistic function (Hsu et al., 1984), Generalized logistic function (Karadavut et al., 2008; Szparaga \& Czerwinska., 2017). Weibull function (Bonner \& Dell, 1976; Bridges et al., 1989; Oraki et al, 2011) and Richards function (Berry et al., 1988; Hara, 1999). Also, some authors have used mathematical expression through the study of germination kinetics after prior physical seed treatments (Torres et al., 1988; Muszynski \& Gładyszewska, 2008; Matwijczuk et al., 2012). The main goal of this study were to (i) to identify the influences of microwave and UV-C radiation on some barley seed germination characteristics. (ii) Choose the predictive fitting model (Logistic or Gompertz function) suited to cumulative barley seed germination curves under the influence of these factors.

\section{Material and Methods}

Seeds of barley (Arivat) cultivar selected for uniform size and shape were first to have soaked in distilled water for 1 hour. After that, seeds have divided into two sets, each set divided into four groups, and each group containing 60 seeds in three replicates. Set one barley seeds have exposed to Microwave radiation (MW) at2450 $\mathrm{MHz}$, for 0 (MW0) as a control, 5 (MW1), 10 (MW2), and 20 (MW3) seconds. While in the set two, seeds were exposed to a different period time to Ultraviolet-C (UV-C) radiation of $254 \mathrm{~nm}$, for 0 (UV0) as a control, 30 (UV1), 60 (UV2), and $\quad 120 \quad$ (UV3) minutes. 
After receiving treatments, the two sets of seeds were then planted under the laboratory conditions in Petri dishes (100 $\mathrm{mm}$ in diameter) with an absorbent paper towel moistened with distilled water. After two days, the start of the experiment, a final number of cumulative seed germination was counted daily at intervals 12-hour, and therefore the percentage of germinated seeds recorded until the eighth day when there have been no more germinated seeds. The seeds have considered germinated when the radical has about $2 \mathrm{~mm}$ long or more. For evaluation of the influence of MW and UV-C treatments on barley seeds, some germination parameters have calculated as follows:

The final percentage of seeds germination (FGP \%) represented the total number of seedlings at the end of the test after seventh days, which calculated as the following formula:

$\mathrm{FGP} \%=\frac{\mathrm{NGS}_{\mathrm{AD} 7}}{\mathrm{TNSP}} \times 100$

NGS AD7: Number of Germination Seeds After 7 Days

TNSP: Total Number of Seeds Planted

The speed germination (S.G) was calculated according to Mohammad et al. (1989) as:

Where G1, G2...Gn are the germination percentage $\times 100$ at the first, second and subsequent days after sowing until the $9^{\text {th }}$ day; 1, 2 and $n$ are the days of first, second ... and final count, respectively.

Germination Index (GI) was calculated according to the following formula of kader (2005):
S. G $=\frac{N G S}{D_{1 s t} C}+\cdots+\frac{N G S}{D F C}\left(\right.$ seed day $\left.{ }^{-1}\right)$

NGS: Number of Germination Seeds

$\mathrm{D}_{1 \text { st }} \mathrm{C}$ : Days of first count

DFC: Days of Final Count

Mean Germination Time (MGT) was calculated according to the following formula of Soltani et al. (2015):

$M G T=\frac{\sum n D}{n}($ day $)$

Where $\mathrm{n}$ is the number of seeds, which have germinated corresponds to the day D observation (not the accumulated number), and $\mathrm{D}$ is the number of days counted from the beginning of germination.

Germination Rate Index (GRI) has calculated according to the following formula of Esechie (1994):

$G R I=\frac{G_{1}}{1}+\frac{G_{2}}{2}+\cdots+\frac{G_{n}}{n}\left(\left(\% \mathrm{day}^{-1}\right)\right.$

$\mathrm{G}_{\text {inf: }}$ is the germination percentage at the point of inflection of Logistic and Gompertz and curves (Ginf) at which growth have been reached to1/2C and $0.368 \mathrm{c}$, respectively. While the maximal rate of germination for the inflection point was calculated as $\mathrm{V}_{\max }=\mathrm{C} \cdot \mathrm{A} / 4$ and $\mathrm{V}_{\max }=$ C.A/e for Log and Gom model, respectively.

$$
G I=(10 \times n 1)+\cdots+(1 \times n 10)
$$

Where $\mathrm{n} 1, \mathrm{n} 2 \ldots \mathrm{n} 9$ are the number of seeds germinated on the first, second, and subsequent days until the 10 th day; 10, 9. . and 1: - are the number of seeds germinated on the first, second, and subsequent days, respectively. 
The Logistic and Gompertz models were used for analyses the cumulative germination curves of barley seeds overtime after the impact of a UV-C and MW radiation. Also, a comparison between the two models was performed separately in each treatment. All computations were made using the excel program. The functions of Logistic and Gompertz were given in the following equations (1) and (2), respectively.

Logistic model

$$
\mathrm{Y}=\mathrm{C} /[1+\mathrm{B} * \exp (-\mathrm{A} * \mathrm{~T})]
$$

Gompertz model

$$
\mathrm{Y}=\mathrm{C} \exp [-\mathrm{B} * \exp (-\mathrm{A} * \mathrm{~T})]
$$

Where: $\mathrm{Y}(\mathrm{T})$ is the cumulative percentage of seeds that have germinated at any fixed time, expressed as a percentage. While, $\mathrm{T}$ means a germination time, expressed as time growing in hours after sowing. $\mathrm{C}$ is that the asymptotic value for $y(T)$, which represents the maximum cumulative percentage of germinated seeds after a long time, while $\mathrm{B}$ and $\mathrm{A}$ are coefficients calculating by the Excel program. To statistically describe the germination process, the following parameters have calculated:

$T_{\text {inf: }}$ is the time of obtaining the curve inflection point of Logistic and Gompertz curve $\left(T_{\text {inf }}=\frac{\ln B}{A}\right)$.

The best-fitting growth curve was done based on the coefficient of determination $\left(\mathrm{R}^{2}\right)$, and mean square error (MSE). The statistical analyses have been used in the experimental study, according to a completely randomized design (CRD), with three replications, each petri dish represents one replicate. To analyses, the results mean comparisons between the treatments have performed by LSD test at a level of 0.05 significance using SPSS 20.

\section{Results \& Discussion:}

\section{Germination characteristics:}

Germination parameters of barley seeds for treatment with microwave have shown in table (1). According to obtained results, most microwave treatment in all exposure time was gave a significant effect on all studied seed germination parameters, except the mean germination time. To compare the values of microwave-treated seeds with untreated seeds, the maximum final germination percentage $(93.33 \%)$, speed germination (6.24), germination rate index (31.19) and germination index (87.67) have been observed a positive effect at a shorter exposure time (10s), which increased by $21.73,44.77,42.87$ and $28.30 \%$, respectively. While the lowest values germination percentage $(66.67 \%)$, speed germination (3.44), germination rate index (18.19) and germination index (56.67) have been given a negative effect at a longer exposure time (20 s), which reduced by $13,22.50,16.67$, and $17 \%$, respectively compared with untreated seeds. Moreover, despite the no-show significant effect on mean germination time, the greatest reductions (3.37) were found at exposure time (10sec) compared to untreated seeds (3.70) in table 1. According to these results, it is clear that the microwave treated had both positive and negative effects on barley seed germination, which are in agreement with a several studies of seed treatments with microwave radiation, for example, wheat (Lazim \& Ramadhan, 2020); barley 
Table (1): Effect of the different exposure times of microwave radiation on some germination characteristics of barley seeds, expressed as mean and standard error.

\begin{tabular}{cccccc}
\hline \multirow{2}{*}{$\begin{array}{c}\text { Exposure } \\
\text { time }\end{array}$} & \multicolumn{6}{c}{ Seed Germination Characteristics } & & \\
\cline { 2 - 6 } sec & $\begin{array}{c}\text { FGB } \\
\%\end{array}$ & $\begin{array}{c}\text { S.G } \\
\text { seed day }\end{array}$ & $\begin{array}{c}\text { MGT } \\
\text { day }\end{array}$ & $\begin{array}{c}\text { GRI } \\
\% \text { day }^{-1}\end{array}$ & GI \\
\hline MW0 & $76.67^{\mathbf{b}} \pm 1.67$ & $4.31^{\mathbf{a b}} \pm 0.34$ & $3.70 \pm 0.15$ & $21.83^{\mathbf{b}} \pm 0.92$ & $68.33^{\mathbf{b}} \pm 1.33$ \\
\hline MW1 & $83.33^{\mathbf{c}} \pm 1.65$ & $5.11^{\mathbf{b c}} \pm 0.08$ & $3.46 \pm 0.13$ & $25.56^{\mathbf{c}} \pm 0.41$ & $77.67^{\mathbf{b}} \pm 2.60$ \\
\hline MW2 & $93.33^{\mathbf{d}} \pm 1.66$ & $6.24^{\mathbf{c}} \pm 0.10$ & $3.37 \pm 0.05$ & $31.19^{\mathbf{d}} \pm 0.49$ & $87.67^{\mathbf{c}} \pm 4.06$ \\
\hline MW3 & $66.67^{\mathbf{a}} \pm 1.59$ & $3.34^{\mathbf{a}} \pm 0.48$ & $3.75 \pm 0.18$ & $18.19^{\mathbf{a}} \pm 1.42$ & $56.67^{\mathbf{a}} \pm 2.03$ \\
\hline L.S.D & 5.43 & 0.98 & N.S & 2.95 & 8.80 \\
\hline
\end{tabular}

FGB: Final germination percentage; SG: Speed germination; MGT: Mean germination time; GRI Germination rate index; GI: Germination index and N.S= Non-significance: The different superscript letters across each column are mean significantly different at $\mathrm{P}<0.05$ level.

(Iuliana et al., 2013; Abu-Elsaoud \& Qari, 2017) and bean (Jakubowski, 2015). Microwave radiation has both positive and negative effects on plant seed germination, depending on the time of exposure. Different germination characteristics in this experiment have affected by time exposure dependent. However, the low exposure time (5 and $10 \mathrm{sec})$ stimulated seed germination, while higher exposure time (20 Sec) inhibited seed germination. Several authors have researched responsible behavior as a mechanism for the positive effects of seed treatment with MW. Al Mashhdani \& Muhammed (2016) and Kretova et al. (2018) observed an increase in amylase activity enzymes, which may be attributable to the positive effect of wheat and barley seed treated with MW. Moreover, an increase in a catalase and superoxide dismutase activity in buckwheat sprouts during microwave seeds treatment have observed by Wang et al. (2018). Also, Chen et al. (2005) observed changes in enzymatic activity and accelerate enzyme-mediated reactions in Isatis indigotica fort seed embryos, leading to an increase in the internal energy of the seed germination treated with MW. While the longer exposure time of an MW radiation may have a detrimental action on the germination seeds (Kuzugudenli, 2018). Results of germination characteristics from barley seed treated with UV-C radiation have been summarized in table (2).

A comparison of mean germination characteristics found that there was no significant effect among treatments in all germination characteristics of barley seeds. Further, in the same table and spite of, noshowed significant effect in all germination characteristics, however, the best treatment with UV radiation were shown from exposure for $120 \mathrm{~min}$ in FGB $(88.33 \%)$ and GI (82.33) compared with untreated seed, which increased by 6 and $7.38 \%$, respectively. While the lowest value has recorded at 60 min exposure time in FGB (78.33) and GI (69.67) compared with untreated seed, which reduced by 6 and $9 \%$, respectively. Results of barley seed germination within the present study could be found agreement or non-agreement with several authors. Sadeghianfar et al. (2019) and Neelamegam \& Sutha (2015) did not find any significant effect on the germination percentage of the maize, 
sorghum, and Groundnut seeds, respectively, when have been exposed to $\mathrm{UV}-\mathrm{C}$ ray up to $60 \mathrm{~min}$. While a significant increase in the germination of mung bean has been observed by Siddiqui et al. (2011) when seeds have treated for 30 minutes. Furthermore, Rupiasih \& Vidyasagar (2016) were observed a stimulation in the germination percentage of wheat seed treated with UV-C rays for up to 180 . While, Lazim \& Nasur (2017) reported that reduced the germination percentage of sorghum seeds irradiated with UV-C rays for 30 and $60 \mathrm{~min}$.

Table (2): Effect of various exposure times on barley seeds from UV-C radiation on some germination characteristics of the barley plant, expressed as mean and standard error.

\begin{tabular}{|c|c|c|c|c|c|}
\hline \multirow{2}{*}{$\begin{array}{c}\text { Exposure } \\
\text { time }\end{array}$} & $\begin{array}{c}|c| \\
\text { FGB } \\
\text { sec }\end{array}$ & $\begin{array}{c}\text { S.G } \\
\text { seed day }\end{array}$ & $\begin{array}{c}\text { MGT } \\
\text { day }\end{array}$ & $\begin{array}{c}\text { GRI } \\
\% \text { day }^{-1}\end{array}$ & GI \\
\cline { 2 - 6 } & $83.33 \pm 6.67$ & $5.19 \pm 0.42$ & $3.40 \pm 0.05$ & $25.64 \pm 2.62$ & $76.67 \pm 5.90$ \\
\hline UV0 & $78.33 \pm 6.01$ & $4.73 \pm 0.53$ & $3.47 \pm 0.19$ & $23.58 \pm 2.69$ & $69.67 \pm 8.01$ \\
\hline UV1 & $85.00 \pm 5.77$ & $5.33 \pm 0.37$ & $3.32 \pm 0.05$ & $26.64 \pm 1.84$ & $79.67 \pm 5.81$ \\
\hline UV2 & $88.33 \pm 1.67$ & $5.54 \pm 0.21$ & $3.34 \pm 0.07$ & $27.72 \pm 1.05$ & $82.33 \pm 2.73$ \\
\hline UV3 & N.S & N.S & N.S & N.S & N.S \\
\hline L.S.D & & &
\end{tabular}

FGB: final germination percentage; SG: speed germination; MGT: mean germination time; GRI germination rate index; GI: germination index and N.S= Non-significance: The different superscript letters across each column are mean significantly different at $\mathrm{P}<0.05$ level.

It is well known that the irradiation of seeds with UV-C changed in the morphology and germinative behavior of plants (Siddiqui et al., 2011). The antioxidants and peroxidase enzyme activities are often one of the several mechanisms of free radicals, which formed in UV irradiation treated seeds. UV-C exposures can lead to the formation of reactive oxygen species (ROS), which are responsible for causing oxidative stress and secondary damage in the plant cell. Moreover, the antioxidants and peroxidase enzyme activities were well known involved in the mechanisms of inhibition of free radicals, which have formed in UV irradiation treated seeds (Rogozhin et al.,
2000; Peykarestan \& Seify, 2012). Further data showed that biochemical parameters mechanism associated with UV-C as lipid peroxidation and proline enzymes might be involved in resistance and effectiveness of irradiation dose (Aboul Fotouh et al., 2014). In addition, low doses of UV-C may be considered inactivation of enzymatic and nonenzymatic protection. Whereas, at high doses of UV-C radiation, it has found acts negatively on growth, development, photosynthesis, and physiological mechanisms in the plants, and it's leading to high concentration ROS which causing cell death (Badridze et al., 2015). 


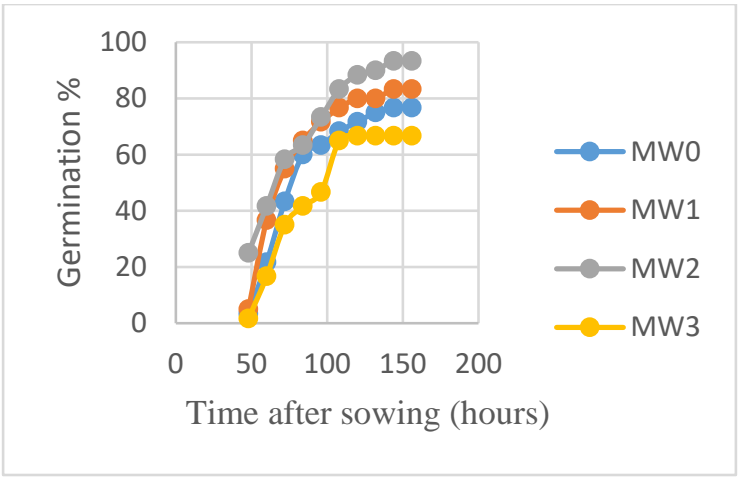

Fig. (1): Mean values of germination percentage of barley seeds as affected by different exposure times from the microwave radiation.

Fig. (1) shows the germination process curves of the microwave treated seeds, which compared to the untreated seeds (control). As introduced in the fig. (1), an increasing in the germination percentage at in short exposure to MW radiation (5 and $10 \mathrm{sec}$ ), however, higher exposure time (20 sec) resulted in significant decreases in the seed germination.

Points on the curves represent the percentage of the actual number of seeds germinated obtained from the counting daily at 12-hour intervals. Germination Percentage expresses the growth of seeds per hour, which has found to be the lowest value in untreated seeds. The germination of the treated seeds at exposure time 2 and 4 hours, and untreated seeds have started after $48 \mathrm{~h}$ of sowing which has reached to 83.33, 93.33, and $76.67 \%$, respectively, during $144 \mathrm{hr}$, while the treated seeds of $6 \mathrm{hr}$ were started after $60 \mathrm{~h}$ of sowing and reached $66.67 \%$ at $108 \mathrm{hr}$.

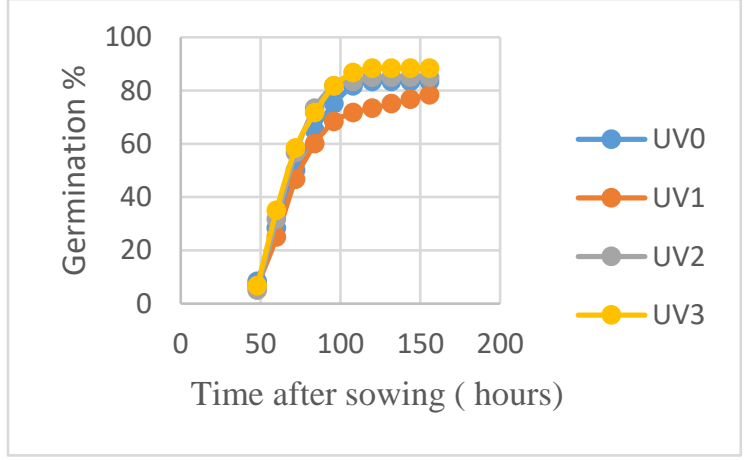

Fig. (2): Mean values of germination percentage of barley seeds as affected by different exposure times from the UV-C radiation

Fig. (2) shows the germination process curves of the UV treatment seeds as compared to the control seeds. Points on the curves describes the percentage germinated of the actual number of seeds obtained from the counting every day at 12hour intervals. The germination of the treated seeds at 60 and $120 \mathrm{~min}$ started after $48 \mathrm{hr}$ of sowing, reaching $85 \%$ and $88.33 \%$ respectively at $144 \mathrm{hr}$, while the untreated and treated seeds at $30 \mathrm{~min}$ started after $48 \mathrm{hr}$ of sowing, reaching 83.33 and $78.33 \%$ at $120 \mathrm{hr}$.

\section{Gompertz and Logistic function analysis of germination:}

Fig. (3) shows the cumulative germination of growth curves barley seeds for various exposure times of the microwave radiation by Logistic and Gompertz functions fitting to measurement points by using a computer program. The germination results obtained from the plotting of Logistic and Gompertz curves based on Eqs. 6 and 7, respectively. The open symbols in each curve represent values obtained from measurements, while the solid symbols were the Logistic and Gompertz functions calculate. Exposure time are: 0s (MW0), 5s (MW1), 10s (MW2) and 20s (MW3). 
Lazim \& Ramadhan/Basrah J. Agric. Sci., 33(2): 28-41, 2020
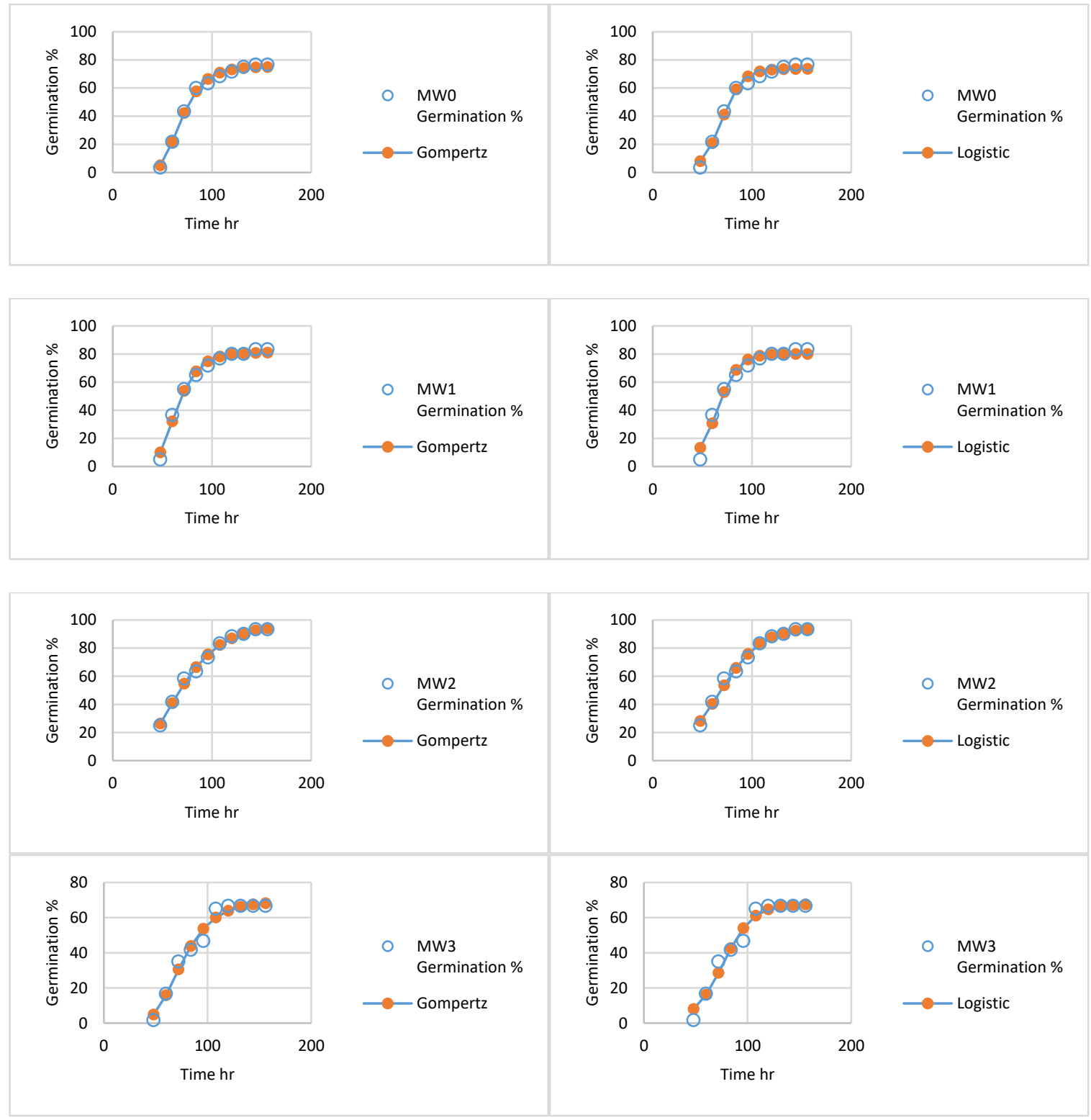

Fig. (3): The experimental and model germination curves of barley seeds as a function of a germination time for various times of microwave radiation exposure. Open symbols (o): Experimental-data; Solid symbols (॰): Model- data. Gompertz and Logistic equations were fitted to the mean values of 3 replications of 20 seeds each per treatment.

Fig. (4) shows the cumulative germination of barley seed growth curves for different UV-radiation exposure times using the Logistic and Gompertz equations, 6 and 7, respectively. In each curve, the open symbols represent the values obtained from measurements, while the solid symbols represent the values of Logistic and Gompertz models calculated. Exposure time: 0min (UV0), 30min (UV1), 60min (UV2), and 120min (UV3). Results from the growth curve fitting of Gompertz and Logistic equations to cumulative germination data in each microwave treatment were summarized in tables (3) and (4), respectively. 


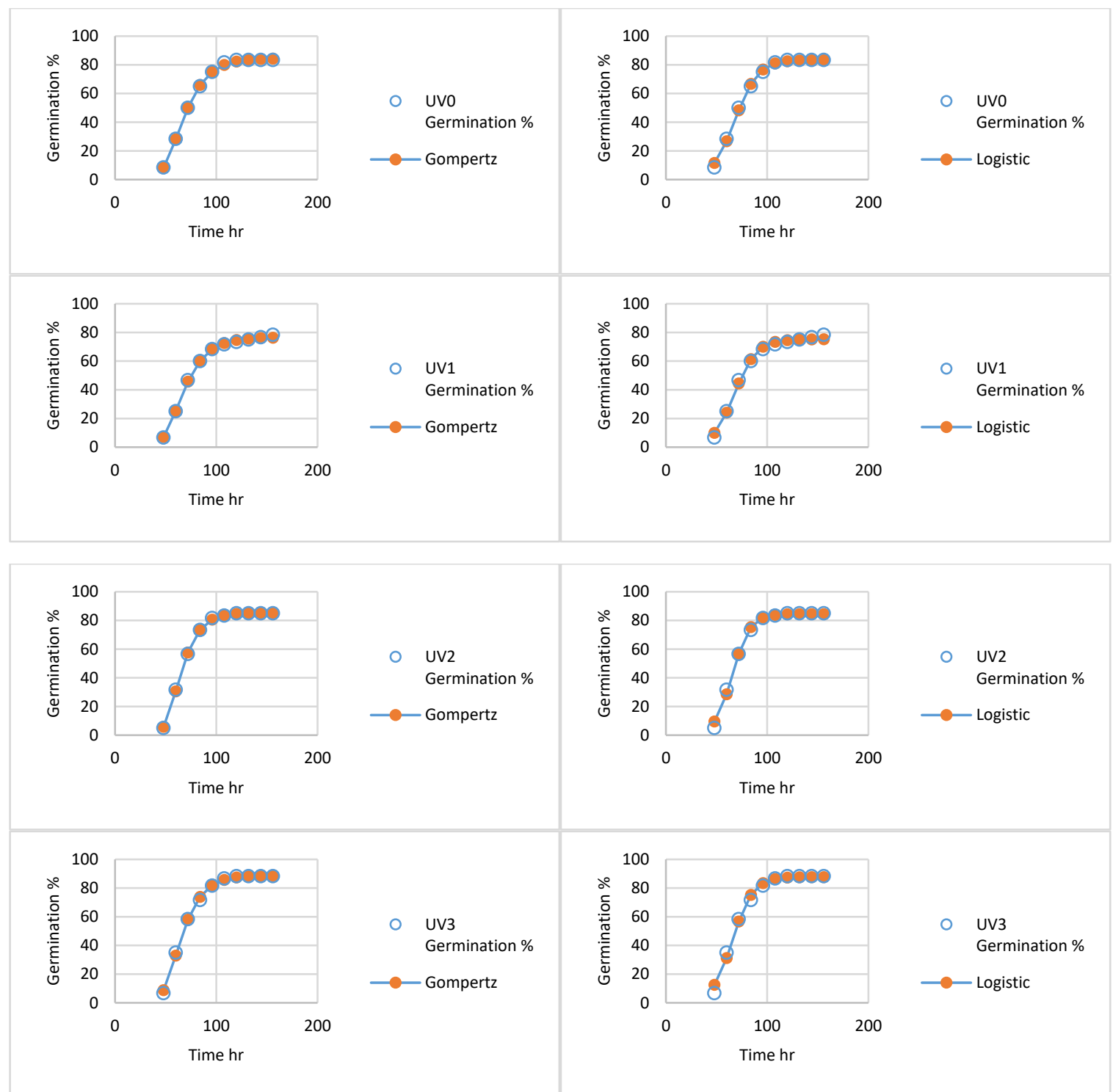

Fig. (4): The experimental and model germination curves of barley seeds as a function of a germination time for various times of ultraviolet radiation exposure. Open symbols (o) is experimental-data; solid symbols (॰) is Model- data. Gompertz and Logistic equations were fitted to the mean values of 3 replications of 20 seeds each per treatment.

The maximum value of asymptotic germination barley seeds using an exposure time MW3 has been recorded in the Logistic and Gompertz growth curve at $94.75 \%$ and $97.24 \%$, respectively. Higher value of germination percentage at the inflection point has been estimated for Logistic $(47.37 \%)$ at MW2 treatment and the lowest for Gompertz (25.42\%) at MW3. While the highest time at the point of inflection has found for Logistic $(76.88 \mathrm{hr}$ ) at MW3, and the lowest has found for Gompertz (57.07 hr) at MW1. Results also show the maximum germination rates have been reached $1.84 \% \mathrm{~h}^{-1}$ for untreated seeds for the Logistic model and to $2.08 \% \mathrm{~h}^{-1}$ for seeds exposed to $5 \mathrm{~s}$ for the Gompertz model. Results from the growth curve fitting of Gompertz and Logistic equations to cumulative germination data in each UV treatment are summarized in the tables (5 and 6), respectively. The asymptotic value 
of the cumulative percentage of germinated barley seeds has been obtained from the fit curve of Logistic and Gompertz equations, where is concluded the highest values at the UV3 treatment in $87.7 \%$ and $88.71 \%$ were observed. The highest value of germination percentage at the inflection point has been estimated at UV3 treatment of Logistic $(43.85 \%)$, while the lowest value has been found at UV1 treatment for Gompertz
(28.15\%). Moreover, the higher time at the point-inflection has been found at UV1 treatment for Logistic $(70.54 \mathrm{hr})$, and the lowest time has been found at UV3 treatment for Gompertz (60.26 hr). Results also show the maximum germination rates have been reached to 2.32 and $2.51 \% \mathrm{~h}^{-1}$ for seeds exposed to $60 \mathrm{~min}$ for Logistic and Gompertz, respectively.

Table (3): Estimated parameters, MSE and $\mathbf{R}^{2}$ values of barley seed germination using Logistic model for microwave radiation.

\begin{tabular}{cccccccrrr}
\hline & \multicolumn{1}{c}{} & \multicolumn{7}{c}{ Inflection point } \\
\cline { 2 - 9 } Treatment & $\begin{array}{c}\mathrm{A} \\
\left(\mathrm{h}^{-1}\right)\end{array}$ & $\mathrm{B}$ & $\begin{array}{c}\mathrm{C} \\
(\%)\end{array}$ & $\begin{array}{c}v_{\max } \\
\left(\% \mathrm{~h}^{-1}\right)\end{array}$ & $\begin{array}{l}\mathrm{T}_{\text {inf }} \\
(\mathrm{h})\end{array}$ & $\begin{array}{l}\mathrm{G}_{\text {inf }} \\
(\%)\end{array}$ & MSE & $\mathrm{R}^{2}$ \\
\hline MW0 & 0.10 & 848.73 & 73.62 & 1.84 & 67.48 & 36.81 & 9.027 & 0.77 \\
\hline MW1 & 0.09 & 470.63 & 80.04 & 1.80 & 68.38 & 40.02 & 16.83 & 0.73 \\
\hline MW2 & 0.05 & 22.45 & 94.75 & 1.18 & 62.22 & 47.37 & 4.90 & 0.91 \\
\hline MW3 & 0.07 & 217.52 & 67.71 & 1.18 & 76.88 & 33.85 & 15.78 & 0.88 \\
\hline
\end{tabular}

$\mathrm{A}, \mathrm{B}$ and $\mathrm{C}$ are model parameters, $\mathrm{R}^{2}$ : correlation coefficient, MSE: mean square error

Table (4): Estimated parameters, MSE and $R^{2}$ values of barley seed germination using the Gompertz model for microwave radiation.

\begin{tabular}{ccccccccc}
\hline & \multicolumn{1}{c}{ Inflection point } \\
\cline { 2 - 8 } Treatment & $\begin{array}{c}\mathrm{A} \\
\left(\mathrm{h}^{-1}\right)\end{array}$ & $\mathrm{B}$ & $\begin{array}{c}\mathrm{C} \\
(\%)\end{array}$ & $\begin{array}{c}v_{\max } \\
\left(\% \mathrm{~h}^{-1}\right)\end{array}$ & $\begin{array}{l}\mathrm{T}_{\text {inf }} \\
(\mathrm{h})\end{array}$ & $\begin{array}{c}\mathrm{G}_{\text {inf }} \\
(\%)\end{array}$ & MSE & $\mathrm{R}^{2}$ \\
\hline MW0 & 0.06 & 59.38 & 75.11 & 1.65 & 68.06 & 27.63 & 3.64 & 0.79 \\
\hline MW1 & 0.07 & 54.33 & 81.05 & 2.08 & 57.07 & 29.81 & 7.87 & 0.74 \\
\hline MW2 & 0.03 & 6.72 & 97.24 & 1.07 & 63.50 & 35.77 & 3.39 & 0.91 \\
\hline MW3 & 0.05 & 27.68 & 69.11 & 1.27 & 66.41 & 25.42 & 12.05 & 0.88 \\
\hline
\end{tabular}

$\mathrm{A}, \mathrm{B}$ and $\mathrm{C}$ are model parameters, $\mathrm{R}^{2}$ : correlation coefficient, MSE: mean square error

Table (5): Estimated parameters, MSE and $\mathbf{R}^{2}$ values of barley seed germination using Logistic model for ultraviolet radiation.

\begin{tabular}{ccccccccc}
\hline & \multicolumn{10}{c}{ Inflection point } \\
\cline { 2 - 8 } Treatment & $\begin{array}{c}\mathrm{A} \\
\left(\mathrm{h}^{-1}\right)\end{array}$ & $\mathrm{B}$ & $\begin{array}{c}\mathrm{C} \\
(\%)\end{array}$ & $\begin{array}{c}v_{\max } \\
\left(\% \mathrm{~h}^{-1}\right)\end{array}$ & $\begin{array}{c}\mathrm{T}_{\text {inf }} \\
(\mathrm{h})\end{array}$ & $\begin{array}{c}\mathrm{G}_{\text {inf }} \\
(\%)\end{array}$ & MSE & $\mathrm{R}^{2}$ \\
\hline UV0 & 0.09 & 447.88 & 83.32 & 1.87 & 67.83 & 41.66 & 2.37 & $\mathbf{0 . 7 7}$ \\
\hline UV1 & 0.09 & 571.60 & 75.24 & 1.69 & 70.54 & 37.62 & 3.88 & 0.76 \\
\hline UV2 & 0.11 & 2036.58 & 84.50 & 2.32 & 63.49 & 42.25 & 3.59 & 0.69 \\
\hline UV3 & 0.10 & 722.08 & 87.70 & 2.19 & 65.82 & 43.85 & 7.06 & 0.72 \\
\hline
\end{tabular}


A, B and C are model parameters, $\mathrm{R}^{2}$ : coefficient of determination, MSE: mean square error

Table (6): Estimated parameters, MSE and $\mathbf{R}^{2}$ values of barley seed germination using the Gompertz model for ultraviolet radiation.

\begin{tabular}{|c|c|c|c|c|c|c|c|c|}
\hline \multirow[b]{2}{*}{ Treatment } & \multirow[b]{2}{*}{$\begin{array}{c}\mathrm{A} \\
\left(\mathrm{h}^{-1}\right)\end{array}$} & \multirow[b]{2}{*}{ B } & \multirow[b]{2}{*}{$\begin{array}{l}\mathrm{C} \\
(\%)\end{array}$} & \multicolumn{4}{|c|}{ Inflection point } & \multirow[b]{2}{*}{$\mathrm{R}^{2}$} \\
\hline & & & & $\begin{array}{c}v_{\max } \\
\left(\% \mathrm{~h}^{-1}\right)\end{array}$ & $\begin{array}{l}\mathrm{T}_{\text {inf }} \\
\text { (h) }\end{array}$ & $\begin{array}{l}\mathrm{G}_{\mathrm{inf}} \\
(\%)\end{array}$ & MSE & \\
\hline UV0 & 0.06 & 45.65 & 84.55 & 1.86 & 63.68 & 31.11 & 0.64 & 0.78 \\
\hline UV1 & 0.06 & 50.36 & 76.51 & 1.68 & 65.32 & 28.15 & 0.88 & 0.78 \\
\hline UV2 & 0.08 & 126.21 & 85.36 & 2.51 & 60.47 & 31.41 & 0.43 & 0.70 \\
\hline UV3 & 0.07 & 67.95 & 88.71 & 2.28 & 60.26 & 32.51 & 1.59 & 0.72 \\
\hline
\end{tabular}

$\mathrm{A}, \mathrm{B}$ and $\mathrm{C}$ are model parameters, $\mathrm{R}^{2}$ : coefficient of determination, MSE: mean square error

Results from the growth curve fitting show that Gom function recorded the lowest MSE in all MW and UV exposure time, as compared with the Log function (Tables 3, 4, 5, and 6). It is concluded that the Gom curve model is more suitable compared to the Log model for MW and UV treatments.

\section{Conclusions:}

The results of this study provided that at the exposure time 10s gives the best values for all seed germination characteristics of barley plants by the microwave treatments. As well as the best results, were recorded in the final percentage germination and the germination index at exposure time $120 \mathrm{~min}$ of UV treatment. The maximum value of asymptotic germination barley seeds has been found within the Gompertz growth curve model with microwave, and ultraviolet treatments for exposure times at $10 \mathrm{~s}$, and $120 \mathrm{~min}$, respectively. Moreover, the maximum germination rate of growth curves has found in the Gompertz growth curve model with the microwave and ultraviolet radiation treatments at exposure times $5 \mathrm{~s}$ and $60 \mathrm{~min}$, respectively. The highest percentage germination value of the point-inflection of the curve has been observed for 10s and 120 min in the Logistic model with microwave and ultraviolet treatments, respectively. The lowest values for MSE in the microwave and ultraviolet seed treatments have been recorded in Gompertz growth curve models compared to Logistic models. In summary, we can conclude that the Gompertz curve model has shown a more fit under the microwave and ultraviolet treatments compared with the Logistic model.

\section{Acknowledgements}

The authors are sincerely thankful to Dr. Sadiq J. Muhsin Head of Department of Machinery and Agricultural Equipment for his scientific research encouragement.

Conflict of interest: Authors declare that there is no conflict of interests.

Samir K. Lazim:

Orcid: https://orcid.org/0000-0002-8650-4829

\section{References}

Abu-Elsaoud, A. M. (2015). Effect of microwave electromagnetic radio frequency on germination and seedling growth consequences of six wheat Triticum aestivum L. cultivars. Advances in Environmental Biology, 9, 270-280. https://www.researchgate.net/publication/28600180 1

Abu-Elsaoud, A. M., \& Qari, S. H. (2017). Influence of microwave irradiations on germination, seedling 


\section{Lazim \& Ramadhan/Basrah J. Agric. Sci., 33(2): 28-41, 2020}

growth and electrolyte leakage of Barley (Hordeum vulgare L.). Catrina, 16, 11-24. https://cat.journals.ekb.eg/article_14255_56f69e030 19247e811accc1f85ba70b5.pdf

Aboul Fotouh, M. M., Moawad, F. G., ElNaggar H. A., Tag El-Din, M. A., \& Sharaf Eldeen, H. A. (2014). Influence of seed treatment with UV-C on saline stress tolerance in green beans (Phaseolus vulgaris L.). Journal of Biological Chemistry and Environmental Sciences, 9, 391-414. https://www.researchgate.net/publication/26327920 $\underline{3}$

Aladjadjiyan, A. (2010). Effect of microwave irradiation on seeds of lentils (Lens Culinaris, Med). Romanian Journal of Biophysics, 20, 213-221. https://www.researchgate.net/publication/207703 684

Al Mashhdani, F. A., \& Muhammed, S. S. (2016). Utilization of microwave treatments for germination and $\alpha$-amylase characteristics in some cereals. International Journal of Current Microbiology and Applied Sciences, 5, 293-306. https://doi.org/10.20546/ijcmas.2016.505.032

Amirnia, R. (2014). Effect of Microwave Radiation on Germination and Seedling Growth of Soybean (Glycine max) Seeds. Advances in Environmental Biology, $\quad 8, \quad 311-314$. https://www.researchgate.net/publication/31682447 $\underline{8}$

Araujo S. S., Paparella, S., Dondi, D., Bentivoglio, A., Carbonera, D., \& Balestrazzi, A. (2016). Physical methods for seed invigoration: Advents and challenges in seed technology, Frontiers in Plant Science, $7, \quad 646$. https://doi.org/10.3389/fpls.2016.00646

Badridze, G., Kacharava, N., Chkhubianishvili, E., Rapava, L., kikvidze, M., Chanishvili, S. H., \& Chigladze, L. (2015). Influence of ultraviolet irradiation and acid precipitations on the content of antioxidants in wheat leaves, Applied Ecology and Environmental Research, 13, 993-1013. https://doi.org/10.15666/aeer/1304_9931013

Berry, G. J., Cawoodf, R. J., \& Flood, R. G. (1988). Curve fitting of germination data using the Richards function, Plant, Cell and Environment, $11, \quad 183-188 . \quad$ https://doi.org/10.1111/j.1365$\underline{\text { 3040.1988.tb01135.x }}$
Bonner, F. T., \& Dell, T. R. (1976). The Weibull function: A new method of comparing seed vigor. Journal of Seed Technology, 1, 96-103. https://doi.org/10.2307/23430404

Bridges, C. D., Wu H., Sharpe, P. J. H., \& Chandler J. M. (1989). Modeling distributions of crop and weed seed germination time. Weed Science, 37, 724-729. DOI: https://doi.org/10.1017/S0043174500072702

Chen, Y. P., LiuI, Y. J., Wang, X. L., Ren, Z. Y., \& Yue, M. (2005). Effect of Microwave and He-Ne Laser on Enzyme Activity and Biophoton Emission of Isatis indigotica Fort. Journal of Integrative Plant Biology (Formerly Acta Botanica Sinica), 47, 849-855.https://doi.org/10.1111/j.17447909.2005.00107.x

Esechie, H. (1994). Interaction of salinity and temperature on the germination of sorghum. Journal of Agronomy and Crop Science, 172, 194-199. https://doi.org/10.1111/j.1439037X.1994.tb00166.x

Govindaraj, M., Masilamani, P., Albert, V. A., \& Bhaskaran, M. (2017). Effect of physical seed treatment on yield and quality of crops: A review. Agricultural Reviews, 38, 1-14. https://doi.org/10.18805/ag.v0iOF.7304

Gupta, M. K., Chandra, P., Samuel, D. V. K., Singh, B., Singh, A., \& Garg, M. K. (2012). Modeling of Tomato Seedling Growth in Greenhouse. Journal of Agricultural Science, 1, 362-369. https://doi.org/10.1007/s40003-012-0035-5

Hara,Y. (1999). Calculation of population Parameters using Richards function and application of indices of growth and seed vigor to rice plants. Plant Production Science, 2, 129-135. https://doi.org/10.1626/pps.2.129

Hsu, F. H., Nelson, C. J., \& Chow, W. S. (1984). A mathematical model to utilize the logistic function in germination and seedling growth. Journal of Experimental Botany, 351, 1629-40. https://doi.org/10.1093/jxb/35.11.1629

Iuliana, C., Caprita, R. , Giancarla, V., Sorina R., \& Genoveva, B. (2013). Response of Barley Seedlings to Microwaves at $2.45 \mathrm{GHz}$. Animal Science and Biotechnologies, $\quad 46, \quad 185-191$. file://C:/Users/lenovo/Downloads/82-999-1PB\%20(4).pdf 


\section{Lazim \& Ramadhan/Basrah J. Agric. Sci., 33(2): 28-41, 2020}

Jakubowski, T. (2015). Evaluation of the impact of pre-sowing microwave stimulation of bean seeds of the germination process. Agricultural Engineering, 2 , 45-56. http://dx.medra.org/10.14654/ir.2015.154.120

Kader, M. A., (2005). A Comparison of Seed Germination Calculation Formulae and the Associated Interpretation of Resulting Data. Journal \& Proceedings of the Royal Society of New South Wales, 138, 65-75. https://pdfs.semanticscholar.org/cbb8/ac13a5a6de8 5cb84b3f7093623aec7ae9b02.pdf?_ga=2.19136760 .1765175035.15980267421401878489.1544551206

Karadavut, U. , Kayi S. A., Palta, C., \& Okur, O. (2008). A growth curve application to compare plant heights and dry weights of some wheat varieties. American-Eurasian Journal of Agricultural \& Environmental Sciences, 3, 888892.

https://www.researchgate.net/publication/23755916 $\underline{2}$

Kretova, Y., Tsirulnichenko, L., Naumenko, N., Popova, N., \& Kalinina, I. (2018). The application of micro-wave treatment to reduce barley contamination. Agronomy Research, 16, 20792087.https://doi.org/10.15159/AR.18.198

Kuzugudenli, E. (2018). Effect of microwave radiation on growth and germination of stone pine (PINUS PINEA L.) seedlings. Applied Ecology and Environmental Research, 16, 2837-2844. DOI: http://dx.doi.org/10.15666/aeer/1603 28372844

Lazim, S. K., \& Nasur, A. F. (2017). The effect of magnetic field and ultraviolet-C radiation on germination and growth seedling of sorghum (Sorghum bicolor L. Moench). IOSR Journal of Agriculture and Veterinary Science (IOSR-JAVS), 10, 30-36. DOI: 10.9790/2380-1010023036

Lazim, S. K., \& Ramadhan, M. (2020). Study effect of a static magnetic field and microwave irradiation on wheat seed germination using different curves fitting model. Journal of Green Engineering, 10, $3188-$

3205. https://www.researchgate.net/publication/34 $\underline{3230736}$

Matwijczuk, A., Kornarzyñski, K., \& Pietruszewski, S. (2012). Effect of magnetic field on seed germination and seedling growth of sunflower,
International Agrophys, 26, 271-278. https://doi.org/10.2478/v10247-012-0039-1

Mohammad, R. M., Campbell, W. F., \& Rumbaugh, M. D. (1989) Variation in salt tolerance of alfalfa. Arid Soil Research and Rehabilitation, 3, 11-20. https://doi.org/10.1080/15324988909381185

Mohsenkhah, M., Mahzoon, M., \& Talei, D. (2018). Microwave radiation, seed germination and seedling growth responses in pepper (Capsicum annuum L.). Horticulture International Journal, 2, 332-336. DOI: 10.15406/hij.2018.02.00072

Muszynski, S., \& Gldyszewska, B. (2008). Representation of He-Ne laser irradiation effect on radish seeds with selected germination indices. International Agrophysics, 22, 151-157. http://www.international-

agrophysics.org/Representation-of-He-Ne-laserirradiation-effect-on-radish-seeds-with-selectedgermination, 106487,0,2.html

Nasur, A. F., \& Lazim, S. K. (2001). The effect of Ultraviolet Radiation on Germination and Growth of Wheat and Barley. Basrah Journal of Agricultural Sciences, 14, 157-167. https://www. researchgate. net/publication/320799155

Neelamegam, R., \& Sutha, T. (2015). UV-C irradiation effect on seed germination, seedling growth and productivity of groundnut (Arachis hypogaea L.). International Journal of Current Microbiology and Applied Sciences, 4, 430443.http://eprints.icrisat.ac.in/14038/

Oraki, H.; Alahdadi, I., \& khajani, F. P. (2011). Sunflower (Helianthus annuus L.) hybrids seeds distribution modelling: Normal, lognormal and weibull models. African Journal of Agricultural Research, 6, 618-623. https://doi.org/10.5897/AJAR10.777

Peykarestan, B., \& Seify, M. (2012). UV irradiation effects on seed germination and growth, protein content, peroxidase and protease activity in red bean. International Journal of Basic and Applied Sciences, $\quad 3, \quad 92-102$. http://www.irjabs.com/files_site/paperlist/r_252_12 1016141830.pdf

Rogozhin, V. V., Kuriliuk, T. T., \& Filippova, N. P. (2000). Change in the reaction of the antioxidant system of wheat sprouts after UV-irradiation of seeds. Biofizika, 45, 730-736. https://pubmed.ncbi.nlm.nih.gov/11040985/ 
Rupiasih, N. N., \& Vidyasagar, P. B. (2016). Effect of UV-C radiation and hypergravity on germination, growth and content chlorophyll of wheat seedlings // AIP Conference Proceeding. 1719, 030035. https://doi.org/10.1063/1.4943730

Sadeghianfar, P., Nazari, M., \& Backes, G. (2019). Exposure to ultraviolet (UV-C) radiation increases germination rate of maize (Zea maize L.) and sugar beet (Beta vulgaris) seeds. Plants, 8, 1-6. https://doi.org/10.3390/plants8020049

Siddiqui, A., Dawar, S., Zaki M. J., \& Hamid, N. (2011). Role of Ultra violet (UV-C) radiation in the control of root infecting fungi on groundnut and mung bean. Pakistan Journal of Botany, 43, 22212224. https://doi.org/10.3390/plants 8020049

Soltani, E., Ghaderi-Far, F., Baskin, C. C., \& Baskin, J. M. (2015). Problems with using mean germination time to calculate rate of seed germination. Australian Journal of Botany, 63, 631-635. https://doi.org/10.1071/BT15133
Sousa, I. F., Neto, J. E. K., Muniz, J. A., Guimaraes, R. M.; Savian, T. V., \& Muniz, F. R. (2014). Fitting non lin arauto regressive models to describe coffee seed germination. Ciencia Rural, 44, 2016-2021. https://doi.org/10.1590/0103-8478cr20131341.

Szparaga, A., \& Czerwinska, E. (2017). Modelling of beetroot seedlings with modified generalized logistic functions. Agricultural Engineering, 21, 107-117.https://doi.org/10.1515/agriceng-2017-003

Torres, M., Boada, P. S., \& Duran, J. M. (1988). Growth analysis by different mathematical models of barley plants after U.V. -A irradiation. Environmental and Experimental Botany, 28, 315321. https://doi.org/10.1016/0098-8472(88)90055$\mathrm{X}$

Wang, S., Wang, J., \& Guo, Y. (2018) Microwave irradiation enhances the germination rate of tartary buckwheat and content of some compounds in its sprouts. Polish Journal of Food and Nutrition Sciences, 68, 195-205. https://doi.org/10.1515/pjfns-2017-0025

\title{
تأثير إثعة الميكروويف والفوق البنفجية - ج على بعض خصائص إنبات بذور الثعير باستخدام نماذج

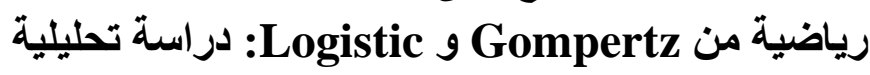

\author{
سمير خيري لازم و مروان نوري رمضان \\ قسم المكائن و الآلات الزر اعية، كلية الزر اعة، جامعة البصرة، العر اق
}

المستخلص: أجريت در اسة مختبرية لتجربتين منفصلتين لمعالجة بذور الثعير باستخدام أشعة الميكروويف و الفوق البنفسيةج. في تجربة الميكروويف عرضت بذور الثعير للأشعة بتردد 2450 ميكاهيرتز لفترات 0 ثانبة (مكف 0) و 5 نثانية (مكف 1) و و

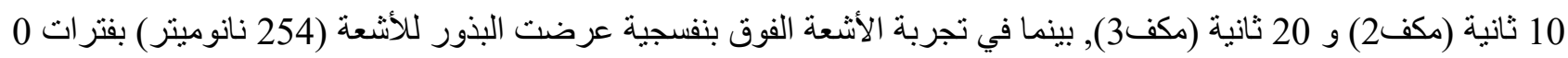

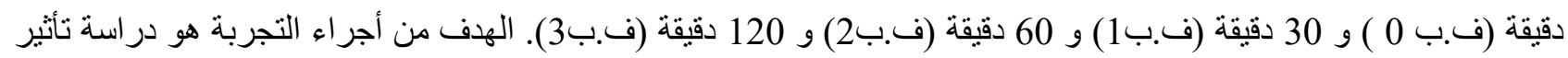

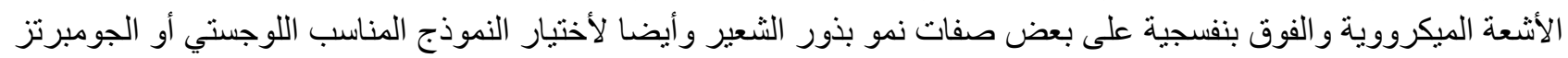

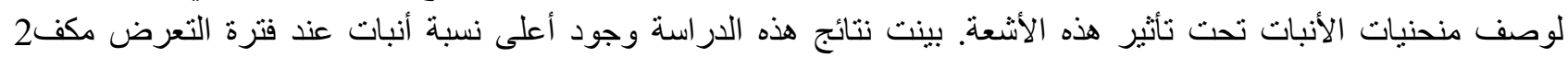

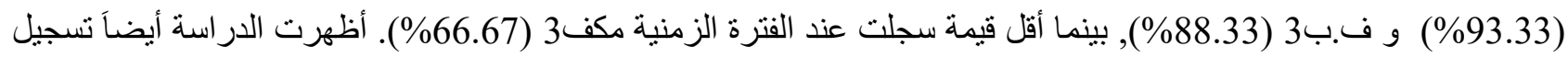
أفضل القيم عند زمن التعرض مكف2 في كل من صفة سر عة الأنبات (6.24 بذرة باليوم) و معدل مؤشر الأنبات (31.19\%

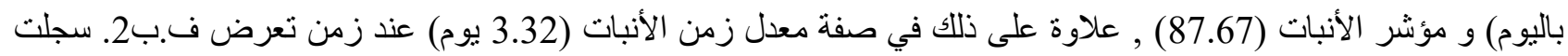

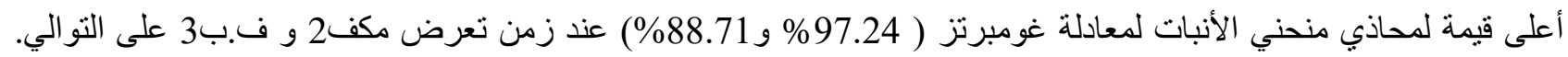

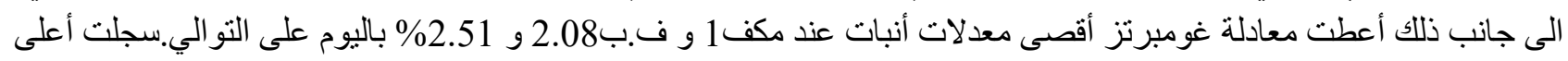

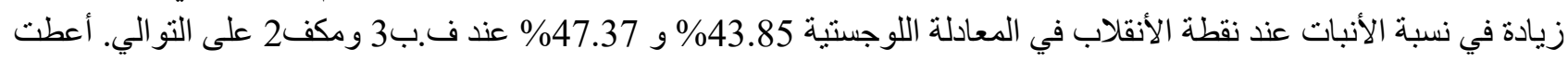

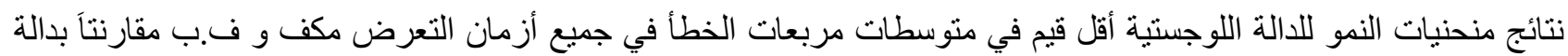

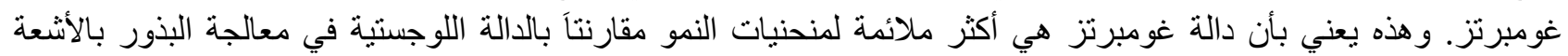
الميكرووية والفوق بنفسجية. 